\title{
THE NON-APPLICATION OF COMPETITION RULES IN POST-CONFLICT DEVELOPMENT
}

\author{
Attila Nagy, PhD Candidate \\ Friedrich Schiller University in Jena, Jena Centre for Reconciliation Studies \\ Leutragraben 1, JenTower Room 15N03, 07743 Jena, Germany \\ attila.nagy@uni-jena.de
}

\begin{abstract}
Competition has been claimed to be a very liberal economic tool where market players are meant to be free in arranging their technologies, production and sales on a particular market. In this paper we are developing a new hypothetical of the functioning of market economies which are in a global sense and considering new markets very different and specific. All the global powers, whose centre of influence might change in time, are trying to gain a bigger share regarding raw materials and potential markets. In post-conflicts societies and in particular in our case study of Kosovo and Serbia we can see the more clear market interests of all local, regional and global powers. The research of post-conflict societies is providing us with some answers regarding the possible future developments in certain societies and regions. The EU made Brussels Agreements in Kosovo has managed to establish new enterprises as a solution of a political compromise where energy, telecommunication and natural resources played a key role. The Washington Agreement has liberalized the infrastructure achievements but in some aspects limited the use of energy and telecommunication infrastructure from certain sources. In this sense we can observe the limited capacity of competition rules application in post-conflict societies and in particular Kosovo in this case. These agreements have therefore limited the influence of economic, strategic and energy related influence from main USA competitors which have not been named in the agreements, but are well known. In both agreements it is visible how economic activities and cooperation is encouraged with various non-economic incentives. Competition is accordingly more of a political will than an economic reality for some in postconflict societies. The introduction of various companies into the Kosovo legal framework and their control by Serbia is an obvious tool how natural resources could be shared for a benefit of citizens where conflict is resolved using free market and competition rules.
\end{abstract}

Keywords: post-conflict, development, Kosovo, Brussels Agreement, Washington Agreement 


\section{INTRODUCTION}

Competition has been seen as tool to achieve a greater satisfaction of customers and ultimately offer more and give a chance to choose. It has been outlined in the EU legal framework that competition is one of the core values in the EU and everyone is free to compete on the free EU market. This understanding is different when it comes to the EU neighbourhood and the various legal approaches trying to ultimately bring these countries closer to the EU, competition norms, market and products. Although very actively participating in resolving conflicts from its neighbourhood and bringing divided sides closer EU has found itself, obviously without its fault, in a very complex situation where EU policies are opposed by some other regional powers. Russian geopolitical interests joined recently by the Chinese are not completely in line with the EU and in some cases directly are the opposite. "The developments are in line with the logic of geopolitical competition, which had developed over the years, but enters a fundamentally new stage, where competition turns into conflict." Although Russia and China are not countries which encourage competition inside its borders their external policies do tend to challenge and make their industry compete on the global level. We will research this clash of systems in some post-conflicts societies mainly focusing on Kosovo and Serbia dialogue and the recent agreements related to the establishment of new entities in Kosovo which surprisingly, solve multiple questions and also are introducing some competition on Kosovo. The importance to research this bright example from Kosovo is even more important when we observe what is happening globally and how some post-conflict states are being left aside. "Certain behaviorisms suggest that a neo-colonialism is spreading again, especially in African countries." In this sense the absence of competition is possibly pushing certain states to a stadium of submission to the interests of some, where again the interests of citizens, consumers and producers are ignored. The research of Kosovo is therefore very valuable for the understanding of competition itself from both the bottom up and top to down perspectives. "Societies in economic and political regime transition are in a danger zone and in great need of attention." ${ }^{3}$ As another aspect of our paper is the research of the post-conflict environments we have to be additionally cautious and have more understanding towards specific needs. The huge influx of people from various conflict states has pushed the EU to act and take

Casier, T., From logic of competition to conflict: understanding the dynamics of EU-Russia relations, Contemporary Politics, Vol. 22, No. 3, 2016, pp. 376 - 394

2 Zepf, V. et al., Strategic Resources for Emerging Technologies, in: Hartard S.; Liebert W. (eds.), Competition and Conflicts on Resource Use, London, 2015, pp. 259 - 272

3 Bringa, T., Transition and Conflict in Multiethnic Postsocialist Societies: The Case of Bosnia-Herzegovina in: Proceedings of a Russian-American Workshop, Conflict and Reconstruction in Multiethnic Societies, The National Academies Press, Washington, 2003, pp. 168 - 181 
into consideration more and various needs, sometimes ignoring its own interests as well. "Workers are bound to their locations by family, community, and culture so wage differentials must surpass significant thresholds in order to function as incentives to move." ${ }^{4}$ Being a world leading economy EU is in constant demand for workers, where many are coming from post-conflict societies such as Kosovo, Ukraine and Syria now and many others before in the previous decades of development of EU member state economies. The presence of a conflict in a certain state also gains the attention and support of others where in the EU neighbourhood it is usually EU and USA on one side and Russia and China on the other. The EU is specifically being challenged by the Russia initiated Eurasian Customs Union (ECU) and Eurasian Economic Union. "The EU's unwillingness to enter into a formal dialogue with the ECU was seen as a confirmation of its geopolitical ambition to build a sphere of influence at the expense of Russia." ${ }^{5}$ Therefore the research and understanding of the Kosovo conflict is vital in the process of trying to find solutions to other conflicts where the same actors are confronted like in Ukraine, Syria, Nagorno-Karabakh or even the ones far from EU borders. All the conflicts and the resolution processes are meant to help local citizens in satisfying their everyday needs and helping the local industry in order to benefit its citizens, control emigration from divided societies and enhance global peace ultimately.

\section{DEVELOPMENT RELATED ISSUES}

We are aiming to pose and answer the research questions and find the best possible match for the post-conflict development in the framework of agreements achieved under the supervision and influence of some foreign stakeholders. As energy, telecommunication and overall resources are important for both local and international economies we will compare the possible mutual influences and their outcomes in the framework of the post-conflict development. Such agreements tend to be highly politicized and therefore the resources, development and overall the competition is not encouraged by them in post-conflict societies but the main aim is its dependence with limited capacities to use resources and govern the economy. From inside such agreements can be seen positive as they are benefiting the overall efforts for reconciliation and promote competition from below but from above the conflict is managed and overall belongs to one global power where competition has not much to say. The polarization of conflicts globally is seen as a trend and is to be blamed for the constant backlog of post-conflict societies and

Shaikh, A., Capitalism : competition, conflict, crises, Oxford University Press, Oxford, 2016, p. 750

Casier, T., From logic of competition to conflict: understanding the dynamics of EU-Russia relations, Contemporary Politics, Vol. 22, No. 3, 2016, pp. 376 - 394 
their development just as it is the case with Kosovo with very few investments and the constant trade war with Serbia.

Such development related issues are in recent times very closely connected to the BRICS group which is joining together in efforts to compete with the West. The main role in this group belongs to Russia and China and they are now not afraid to openly compete and even contrast the various measures and politics applied by EU and USA. "Despite the realpolitik language of the great powers, they use economic tools to achieve their objectives or strengthen their positions." ${ }^{6}$ Since the majority of the countries orientates to a certain great power there are only few countries on the crossroads, usually the post-conflict countries such as Ukraine, Syria, Nagorno-Karabakh and finally Kosovo which will also serve as our case study in this paper. As everywhere on the globe the economic interests of a certain country are not represented directly in the interference to the local economy but more in the sense of having their multinational companies do business there, ideally not respecting competition rules. "Hence, while the methods of mercantilism could always be dominated by the methods of war, in the new 'geo-economic' era not only the causes but also the instruments of conflict must be economic." Therefore the issue of gaining new sites to mine resources and place products for sale are in a constant demand. All political systems or groups of countries are looking for exclusivity, both in the sense of excavations and trade. This position, as some would say monopoly, is a burden to every democracy and serves as a target to their enemies with an aim not to limit it but more to allow themselves do the same elsewhere. "Rather, almost all of successful export-oriented growth has come with selective trade and industrialization policies." 8 It is evident that exporting technology or technologically advanced goods will be always in a huge demand, especially in post-conflict countries where the production industry has been demolished. Such post-conflict countries might have resources and raw materials which could be traded off for technology and know-how instead of goods which that way also limit their development potentials. The race for raw materials has never stopped and in recent times it intensified due to both scarcity of some and due to the obvious time limited availability of other, like e.g. Petrol. "Yet the message should be that for emerging technologies, no matter how advanced they are or how effective and efficient, the materials side could be a show stopper both

6 Bayramov, A., Conflict, cooperation or competition in the Caspian Sea region: A critical review of the New Great Game paradigm, Caucasus Survey, 11 Jun 2020, pp. 1 - 20

7 Luttwak, E. N., From Geopolitics to Geo-Economics: Logic of Conflict, Grammar of Commerce, The National Interest, No. 20, 1990, pp. 17 - 23

8 Shaikh, A., Capitalism : competition, conflict, crises, Oxford University Press, Oxford, 2016, p. 494 
on short, mid and long term." ${ }^{\prime}$ Therefore guaranteeing the undisturbed access to certain resources is of a key importance at the moment, even by initiating conflicts in some countries with an aim to make them a dependant post-conflict society which will on a long term be a stable source of resources but politically completely subordinated to their liberator. In this way the political, sometimes even military, assistance is usually paid back in the fact of accessibility to resources. When we speak about resources it has to be mentioned that also the geopolitical location of some states could be of vital importance, so is the case with Ukraine, Syria and Kosovo. States in the EU neighbourhood have a strategic importance and their belonging to some and not the other is more important than the availability of resources per se. The story of Kosovo started in 1999 but later continued in 2008 with the self-proclaimed independence and has since then gained the support of many UN and EU member states but failed to gain the unanimous recognition of the UN and EU as a whole. EU has a status neutral position towards Kosovo which has also in 2013 produced the "Brussels Agreement" ${ }^{10}$ as a tool to pacify Serbia-Kosovo relations and EU internal struggle as well. The Brussels Agreement (BA) regulates many aspects of everyday life in Kosovo, with an aim to help its citizens primarily to have a normal life. As far as economy and development are concerned there have been some solutions made in the telecommunication and energy sector which have advanced since then. On the other hand many questions have remained open and one of them is the management of the big water reservoir (Gazivode Lake on Serbian or Ujmani Lake on Albanian) on North Kosovo. As the lake is of a tremendous importance for development and industry it has been a hard bone to discuss and only the previous USA President Donald Trump has managed to bring the Serbs and Albanians agree about the way to share this valuable resource. In the "Washington Agreement"11 as signed in 2020 the Lake

9 Zepf, V. et al., Strategic Resources for Emerging Technologies, in: Hartard S.; Liebert W. (eds.), Competition and Conflicts on Resource Use, London, 2015, pp. 259 - 272

10 Kosovo, Republic of., The Republic of Kosovo Government Program on the Brussels Dialogue 2014 - 2018, Prishtina, 15 January 2015, [https://kryeministri-ks.net/wp-content/uploads/docs/Kosovo_Government_Program_for_Brussels_Dialogue_2014-2018_150115.pdf] Accessed 20 March 2021

With chapter 35, Serbia will be obliged to fully implement the Brussels agreements and to reach a legally binding international agreement with Kosovo. Such a conditioning on Serbia, most likely to be adopted in the near future, has come as a result of the hard work of the Kosovo Government which has managed to provide factual evidence of Serbia's failure to meet its obligations in implementing the reached agreements.

11 Republic of Kosovo., Implementation Plan of the Washington Agreements Economic Normalisation Between Kosovo and Serbia, [https://kryeministri-ks.net/wp-content/uploads/2020/10/Implementation-Plan-for-the-Washington-Agreement_19102020.pdf] Accessed 20 March 2021

The Washington Agreement (Economic Normalization) has been signed in Washington on $4^{\text {th }}$ September 2020 between President Aleksandar Vucic for Serbia and Prime Minister Avdullah Hoti for Kosovo during a meeting in White House hosted by USA President Donald Trump. 
issue is solved and will be used by both parties to the benefit of all citizens. Still many other challenges have been put in front of the Serbian and Kosovo government which have both agreed to align their policies with USA and EU in a much broader way which has accordingly brought them into confrontation and possible future economic isolation from the Russian and Chinese influence.

\section{COMPETITION RULES IN POST-CONFLICT SOCIETIES}

Competition is present in many different forms on the global level of trade. Only some patterns are very typical for post-conflict societies. Also it is typical to see how societies are responding to the fact of scarcity of some resources and their unavailability on the market. "The statistical results demonstrate that scarcity is no cause of internal violent collective action, which would be a very valuable insight by itself." ${ }^{12}$ Obviously societies which need resources will not solely blame their governments for the scarcity but the others, usually their neighbours, previous or even future enemies. The economic needs and demands are in a situation of scarcity seen completely differently and not within a prism of economy but more with a national and ethnic connotation. "Where the differences are of an ethnic nature, competition for the scarce goods of modernization may be increased and, thus, ethnic relations aggravated." 13 The territorial dimension as we have previously mentioned is very important and if a resource is kept by one side or recovered by the other it serves as an initiation of conflict boosting mechanism. The recently found Oil supplies in the waters around the divided island of Cyprus have boosted the many decades long conflict, in such cases the divided sides which do not want to share anything in common suddenly want to cooperate, share and reach an agreement. Same applies to the find of valuable metals, gold and diamonds in Africa where many resources are misused in an attempt to maintain a conflict on various levels thus calling such materials dirty as either the way or purpose of their excavation is unlawful. "Some mining of such conflict metals is brutally controlled by the conflicting parties and revenues obtained are financing purchases of weapons, hence further fanning the conflict." 14 Therefore as we turn the box we can observe that both the scarcity and availability of resources can start or boost conflicts. Accordingly, only the fair share of resources for which no final and gen-

12 Wittek, R., Resource competition and violent conflict: Cross-cultural evidence for a socio-ecological approach, Zeitschrift fur Ethnologie, No. 115, 1990, pp. 23 - 44

13 Khazanov, A. M., Ethnic and National Conflicts in the Age of Globalization, in: Proceedings of a Russian-American Workshop, Conflict and Reconstruction in Multiethnic Societies, The National Academies Press, Washington, 2003, pp. 162 - 167

14 Hageluken, C., Closing the Loop for Rare Metals Used in Consumer Products: Opportunities and Challenges, in: Hartard S.; Liebert W. (eds.), Competition and Conflicts on Resource Use, London, 2015, pp. $103-119$ 
eral solution is present today globally can serve as a solution. "This is how the logic of competition follows its own dynamics: reading everything through a prism of competition and rivalry, each negative action is understood as necessitating a counter reaction." 15 This is also the aim of our work to research the agreements which have been previously taught to be impossible but now are in the process of implementation. Both The Brussels Agreement (BA) and The Washington Agreement (WA) are bright examples how outcomes can be brought out of situations being thought to be in a permanent dead end. The key solution found in both agreements is the fact of sharing resources and most importantly sharing rights, duties and competences in a mutually acceptable way. Obviously the will to reach such agreements had to pass a long way to get to this position and we can also argue that the moment was not the right previously. Similarly to the Kosovo case the post-conflict countries in the post-Soviet space tend to reach similar agreements to similar conflicts they have in the sense of ethnic, territorial and resource based disagreements. The permanent struggle to gain something and evolve is present in every society, some just need a decade or two to recognize that need and to accordingly position themselves in their region and broader. "Since 2000 the newly independent regional states have also been recognized as the players of the new great game due to their economic and political positions." ${ }^{16}$ Some states initially do not have such an importance locally or as regional or global players. So was the case with Azerbaijan which has been seen as an important player in the Oil sector and the Caspian Sea region just to be able to after some 30 years turn the conflict with Armenia into its own benefit. The new position of Azerbaijan against Armenia has evolved out of its resource based policy which has been recognized by many and most importantly Russia which silently supported the recent 2020 Autumn War in Nagorno-Karabakh. With this recent war in Nagorno-Karabakh a big benefit is also claimed by Russia as it has somehow stabilized the political situation in the Caspian region and therefore secured the intact flow of goods and raw materials globally and from Iran specifically into this region and wider. Other great powers such as EU also tend to stabilise and outline the short and long term flow of raw materials and goods into the EU. "During 2009 and 2010 the Ad Hoc Working Group on Defining Critical Raw Materials of the European Commission evaluated 41 non-energy raw materials, out of which 14 were identified as critical for the EU economy." ${ }^{17}$ Therefore keeping on mind the sources, paths and stability of

15 Casier, T., From logic of competition to conflict: understanding the dynamics of EU-Russia relations, Contemporary Politics, Vol. 22, No. 3, 2016, pp. 376 - 394

16 Bayramov, A., Conflict, cooperation or competition in the Caspian Sea region: A critical review of the New Great Game paradigm, Caucasus Survey, 11 Jun 2020, pp. 1 - 20

17 Hageluken, C., Closing the Loop for Rare Metals Used in Consumer Products: Opportunities and Challenges, in: Hartard S.; Liebert W. (eds.), Competition and Conflicts on Resource Use, London, 2015, pp. 
the suppliers EU is also keen to maintain and establish good relations with partners who are supplying raw materials needed for the smooth run and continuity of the EU democracy. Also both on a short and long run EU wants to encircle its geopolitical positions into which Ukraine and the Eastern Partnership countries might not fall but certainly the Western Balkan countries including Serbia and Kosovo do belong.

\section{SERBIAN INTERESTS AND COMPETITION RULES}

The long lasting conflict between Serbs and Albanians in Kosovo has stepped into a new stadium with the 2008 Kosovo declaration of independence, which has been support by some half of the UN member states so far and almost all EU member states but five. Accordingly the Serbs in Kosovo have also been included into this recognition issue and the ones on North Kosovo have boycotted Kosovo institutions with the support of Serbia while the ones inhabiting Serbian municipalities (enclaves) South of Ibar River have accepted them. Our aim is to deal with institutions which have an economic connotation and have been used in this decade long conflict. Serbia continued to use in North Kosovo its Postal services, Telecommunication/Mobile providers and most importantly controlled Electricity. Electricity is vital for every household and even when there have been frequent cuts in North Kosovo it was served with electricity throughout this period, interestingly without a successful debt collection mechanism. As this and many other issues had to be solved at some moment the 2013 Brussels Agreements has dealt with them in more detail. "Discussions on Energy and Telecoms will be intensified by the two sides and completed by June $15 .{ }^{\prime 18}$ With the developments in the Energy and Telecommunication fields we will go into more detail in the following chapters whereas an additional step in the process of conflict resolution has been agreed. The future establishment of the Association/Community of Serbian municipalities (A/C) with a presently unclear legal status and possible future activity in various economic fields has also been envisaged. "The Association/ Community will exercise other additional competences as may be delegated by

$103-119$

18 Kosovo, Republic of., Law No. 04/L-199 on ratification of the First International Agreement of Principles Governing the Normalization of Relations between the Republic of Kosovo and the Republic of Serbia, [https://gzk.rks-gov.net/ActDocumentDetail.aspx?ActID=11205] Accessed 21 March 2021

Serbia, Republic of., Brussels Agreement, [https://www.srbija.gov.rs/cinjenice/en/120394] Accessed 21 March 2021

The Brussels Agreement is treated as an international agreement and has a form of a law in Kosovo. In Serbia it is treated as a written document of various acts/changes to be made and implemented which have been mutually agreed during the talks in Brussels 
the central authorities." ${ }^{19}$ As until now, almost one decade of its prescribed future establishment, the A/C has not yet been formed and we can just guess how it will look like. Accordingly, to the Serbian side, it will have the authority like Republika Srpska in the sovereign state of Bosnia and Herzegovina whereas according to Kosovo officials, it will be just an advisory body to The Serbian Municipalities in both North and South Kosovo, with a form of an NGO.

\subsection{Serbian telecommunication enterprises in Kosovo}

One of the big successes of the BA is the agreement and practical implementation of the agreements related to telecommunications. Since 2008 the phone lines between North and South Kosovo have been interrupted, they had different Mobile providers and in fact functioned as two different state systems, now this is changing and the customers on North and South Kosovo will be able to call each other. "On fixed telephony a full license for fixed telecommunications services will be issued to a NewCo, subsidiary of a Serbian company registered in accordance with the Kosovar regulatory framework." 20 The landline network used and based in North Kosovo will be now a separate new entity in this framework and connected to Kosovo, similarly to the Serbian state owned MTS mobile provider which has been widely used in North Kosovo. Interestingly the other Mobile/Cell phone providers present in Serbia were not active on the North Kosovo market. "The temporary authorization will expire once the Kosovo authorities issue a new full, unrestricted, mobile telephone license as a result of a tender/auction." ${ }^{21}$ The issue of tendering a new provider is very interesting since neither Kosovo has a need for a new provider and neither Serbs or Serbia in Kosovo want to give up on its provider. "Telekom Srbija a.d. Beograd is the founder of MTS D.O.O. and its sole member with $100 \%$ stake." 22 Although everything is possible and even the privatization of the North Kosovo Mobile network, MTS doo, is possible this transfer of assets, service territory and conflict resolution mechanism is a very good example

19 Ibidem

In Kosovo many settlements with a Serb majority have a status of a separate municipality. The four municipalities on North Kosovo namely: Kosovska Mitrovica, Zvecan, Leposavic and Zubin Potok exercise a very autonomous decision making and are directly and openly supported by Serbia.

20 Office for Kosovo and Metohija., Telecommunications, [http://www.kim.gov.rs/eng/p05.php] Accessed 22 March 2021

21 Ibidem

22 MTS D.O.O., O Nama, [https://mtsdoo.com/o-nama/] Accessed 20 March 2021

In keeping with the referenced agreement and the action plan, the Regulatory Authority of Electronic and Postal Communications (RAEPK) entered mts D.O.O. into the register of electronic communications and granted to it a full licence for fixed telecommunications and a temporary authorization for mobile telecommunications which entered into force on December 16th, 2016. 
how conflict sides can agree for the common benefit of citizens. Although MTS Serbia had previously a dominant position on the North Kosovo market, which has not changed until now, the new balancing mechanism is a very good tool in achieving not just more competition but definitely a better quality in providing services in this sector.

\subsection{Serbian electricity enterprises in Kosovo}

Regarding electricity a very interesting and complex solution has been agreed in Brussels in order to solve the case of unpaid electricity bills in Kosovo, among others. The Serbian side will be allowed to establish, according to Kosovo law, two companies from which one will be a power trading company and the second a power supply company named 'ElektroSever'. This company or Društvo Elektrosever D.O.O. ${ }^{23}$ is meant to solve the issue of unpaid bills in North Kosovo and establish a stable system of future collection and thus energy stability overall. Both companies in Kosovo will be initiated and managed by Elektro Privreda Srbije (EPS) which is a Serbian state owned electricity company, having a monopoly position on the Serbian market itself. As far as competition is concerned it is very important to note that a new electricity trading company will be established in Kosovo which will help in establishing competition and market rules. "This company will apply for, and be granted a license that covers import, export and transit." ${ }^{24}$ Therefore it is rightly argued by Kosovo that the Serbian side will get a lot of opportunities with this agreement and even be able to spread its business in favour of the state owned EPS in Kosovo and wider. Both Kosovo and Serbia have arguments and are claiming that their economic interests are endangered by the acts of the other side. "In the meantime, Serbian side shall continue appealing and trying to talk with Priština to stop stealing electricity from within the RG CE ENTSO-E power system, given that it jeopardized the energy stability of the entire region." ${ }^{25}$ Energy stability in the region might not be in such a danger but the unpaid bills in North Kosovo are certainly a big and not sufficiently reasoned obstacle for the functioning of normal life. The constant mutual claims of Ser-

23 Business Registration Agency of Kosovo., Drustvo Elektrosever D.O.O., [https://arbk.rks-gov.net/page. aspx?id=2,38,174962] Accessed 20 March 2021

24 Conclusions of the EU facilitator on the implementation of the 2013 Energy Agreement, [http:// www.kim.gov.rs/eng/p20.php\#][https://kryeministri-ks.net/wp-content/uploads/docs/150825-Conclusions-on-the-Implementation-of-Energy-Agreement_en.pdf] Accessed 21 March 2021

25 Office for Kosovo and Metohija and Office for the Coordination of Affairs in the Process of Negotiation with the Provisional Institutions of Self-Government in Priština., Progress Report on the Dialogue Between Belgrade and Priština (Covering the period from May 1 to December 15, 2018), [http:// www.kim.gov.rs/doc/pregovaracki-proces/Sestomesecni\%20izvestaj\%20o\%20dijalogu\%20dec\%20 2018\%20\%2011\%2002\%202019\%20en.pdf] Accessed 20 March 2021 
bia and Kosovo against each other are continuing to be a burden as both parties claim both the infrastructure and resources found in Kosovo to its own side. A very interesting example is the company of JP PK „KOSOVO“ - Obilić ${ }^{26}$ which functions in the framework of EPS but has been moved from its base in Obilić Kosovo to Belgrade, Serbia. Obviously, companies can't work if there are no resources which are meant to be excavated and similarly the resources in Kosovo can't be excavated if the conflict continues and blocks the development and work of companies such as Trepcha which has halted its mining since many years before.

\subsection{Serbian resources in Kosovo}

The Serbian resources in Kosovo or the non-accessible resources by Serbia in Kosovo are forming a long list and certainly are benefiting Kosovo economy as much as they are harming the Serbian. Together with the recent trade war and ban of Serbian products from the Kosovo market by the imposition of $100 \%$ taxes are just a piece in the pile of disagreements between these two sides. Therefore the biggest success and advance has at the moment been made in the sector of telecommunication and it should be of a bigger focus and also serve as a benchmark for other topics. "This allocated frequency spectrum will be used for the provision of public mobile telephone services and mobile broadband services on a technologically neutral basis, i.e. 2G, 3G, 4G technology will be used in allocated spectrum on all existing sites..." ${ }^{27}$ The WA is in some instances going directly against the interests of both Serbia and Kosovo and also its citizen altogether. "Both parties will prohibit the use of $5 \mathrm{G}$ equipment supplied by untrusted vendors in their communications networks." 28 In other words this means that the equipment supplied by the Chinese company Huawei will not be accepted on these markets and it is a big problem when we know the popularity, price and accessibility of its products on the global markets and especially in Serbia which has a very specific and friendly relationship with China. This is a measure meant to support the USA recent animosity case with China and Huawei but not just with them, as the other big competitor of USA in the region Russia has also been targeted by the WA. Since, both parties will diversify their energy supplies. ${ }^{29}$ This solution means for Serbia

26 EPS JP PK „KOSOVO“ - Obilić, O nama, [http://pkkosovo.rs/]Accessed 20 March 2021

27 Office for Kosovo and Metohija., Conclusions of the EU Facilitator on Telecoms, 13 November 2016, [http://www.kim.gov.rs/eng/p23.php] Accessed 22 March 2021

Serbia will send to the ITU agreeing that code +383 can be allocated to Kosovo

28 Republic of Kosovo., Implementation Plan of the Washington Agreements Economic Normalisation Between Kosovo and Serbia, [https://kryeministri-ks.net/wp-content/uploads/2020/10/Implementation-Plan-for-the-Washington-Agreement_19102020.pdf] Accessed 20 March 2021

29 Ibidem 
that it should not be in such a close connection with the Russian energy suppliers, which is hard for every European country, but most likely turn more and more to the USA supplied energy resources instead. This is a very interesting solution also going in line with the various competition rules and expectations, but still on the global level it is more acceptable to ban competition than to limit it on a local level to ordinary consumers. "The dominant position holds an undertaking that because of its market power in the relevant market can substantially independently operate in relation to actual or potential competitors, customers, suppliers or consumers." 30 Therefore all the previous agreements and in specific the BA and WA have to be more in harmony and less in conflict as we keep adding on a daily basis issues which are dividing the sides not just in our Serbia-Kosovo case study but much wider in other post-conflict or even ordinary societies.

\section{KOSOVO INTERESTS AND COMPETITION DEVELOPMENT}

The situation in Kosovo is very complex in the sense of understanding and the realization of Agreements from Brussels and Washington. As an outcome of this on the recent parliamentary elections in Kosovo the majority has elected a government which is negating the outcomes of the talks with Serbia and supports the permanent confrontation idea. Additionally they have an idea of going back and resetting everything according to what was the factual situation before these agreements. "In addition, the Technical Dialogue has resulted in draft agreements on telecommunications and energy issues that have been finalized during the dialogue for normalization." ${ }^{11}$ Accordingly the focus of the Kosovo government should be not just the normalization of relations with Serbia but the work on the property issues for the rest of enterprises which could rise employment in Kosovo. There is a usual Disclaimer ${ }^{32}$ in the recent agreements regarding the property rights in Kosovo and one of the biggest steps is to deal with the Trepcha mine which is of a vital interest to all the citizens of Kosovo. Mining was one of the biggest sectors for job creation in Kosovo before the conflict and especially in the previous Communist era where jobs and incomes were more secure. "In this case, one should expect

30 Art.15 of the Law on Protection of Competition, Official Gazette of the RS No. 51/2009 and 95/2013

31 Kosovo, Republic of., The Republic of Kosovo Government Program on the Brussels Dialogue 2014-2018, Prishtina, 15 January 2015, [https://kryeministri-ks.net/wp-content/uploads/docs/Kosovo_Government_Program_for_Brussels_Dialogue_2014-2018_150115.pdf] Accessed 20 March 2021

32 Kosovo considers that, in accordance with Kosovo Constitution and Laws, and international law , namely UNSCR 1244 and respective UNMIK Regulations, the property within the territory of Kosovo is ownership of the Republic of Kosovo.

Serbia considers that, that in accordance with domestic and international law, namely UNSCR 1244, property within the territory of Kosovo is ownership of Serbia, under specific provincial regulation and in full accordance with the Constitution of Serbia. 
growth of nationalism as a reaction to the difficulties and shortcomings connected with the globalization process." 33 This feeling of globalization is typical not just to post-conflict societies but to other transitioning societies in Eastern Europe. On the end this radical shift in the Kosovo politics is coming at the same time and together with other similar shifts in Eastern Europe like Hungary and Poland but also including BrExit on the wider EU political scene.

\subsection{Kosovo and the Serbian telecommunication enterprise}

It can be said that the biggest and quickest change has been achieved in the telecommunications sector from all the topics dealt within the BA. Although the postal service is also vital for the functioning of the economy and in particular for the state administration it was one of the most straight forward agreements where the market has been shared between the providers. "Current operations of the two postal operators of universal postal services on the territory of Kosovo and Metohija will not change with the signing of the Protocol on establishing the postal traffic." ${ }^{34}$ When it comes to Mobile operators there are two of them in Kosovo from which Vala is a state owned operator and IPKO is private. Accordingly it can be stated that the Kosovo market does not suffer from monopoly in this sense but when it comes to providing services to state institutions it is different. On North Kosovo it was demanded that the newly formed state institutions also get involved into the formerly signed contracts from the Kosovo state. "These Priština demands received support of the EU facilitator, who invoked Pristina's decision whereby Vala is the only operator allowed to provide mobile and land line telephony and the Internet services to the so-called state institutions in the territory of Kosovo and Metohija." ${ }^{35}$ This issue can be seen everywhere where autonomy is seen as an issue and the authorities who aim at more power will also request the power to sign contracts by themself. In this case the aim to argue for the contracts regarding state institutions are also not related to the price but to the power and autonomy

33 Khazanov, A. M., Ethnic and National Conflicts in the Age of Globalization, in: Proceedings of a Russian-American Workshop, Conflict and Reconstruction in Multiethnic Societies, The National Academies Press, Washington, 2003, pp. 162 - 167

34 Office for Kosovo and Metohija., Annex 3 of the Memorandum on understanding between Chamber of commerce and industry of Serbia and Kosovo Chamber of Commerce, [http://www.kim.gov.rs/docl pregovaracki-proces/2.2\%20Annex\%203\%20MoU\%20PKS-PKK\%20febr\%202015\%20eng.pdf] Accessed 20 March 2021

35 Office for Kosovo and Metohija and Office for the Coordination of Affairs in the Process of Negotiation with the Provisional Institutions of Self-Government in Priština., Progress Report on the Dialogue Between Belgrade and Priština (Covering the period from May 1 to December 15, 2018), [http:// www.kim.gov.rs/doc/pregovaracki-proces/Sestomesecni\%20izvestaj\%20o\%20dijalogu\%20dec\%20 2018\%20\%2011\%2002\%202019\%20en.pdf] Accessed 20 March 2021 
of an institution to care for its own arrangements. "The Serbian side rejected the proposal since this solution was older than the Arrangements regarding Telecommunications, and maintained that the 'mts d.o.o.' should provide these services to the judicial institutions in the north of Kosovo and Metohija." ${ }^{36}$ It can also be seen as a challenge since if an agreement gets signed for a period longer than the actual prescribed duration time of the MTS doo company itself it can endanger the work of the court. As we have argued before the future status of MTS doo might be unclear in the Kosovo legislation but concerning local demands and North Kosovo politics it is hard to imagine it leaving and giving up its market and infrastructure to another company. "It will not be a third mobile operator in Kosovo, because in order to do so international tendering of multiple bidders is required as provided by legislation of the Republic of Kosovo. This temporary permission for this company will be valid until the opening of the international tender for a third mobile operator." ${ }^{37}$ For such a small market a new provider might also not be economically feasible and the already present national predisposition of the MTS doo shows that the final agreement is still far. Even if Serbia decides to sell the main MTS Company in Serbia the Kosovo branch of its MTS doo could still remain and potentially be owned by one of the municipalities on North Kosovo or even the future Association/Community of Serbian municipalities.

\subsection{Kosovo and the Serbian electricity enterprises}

In the sense of economy and development the biggest challenge and obstacle in Kosovo and actually in North Kosovo is the challenge related to unpaid electricity bills. The official Kosovo electricity supply company KEK (Kosovo Energy Corporation) has never managed to collect the money for unpaid bills in full on North Kosovo. The resistance of the Serb minority on North Kosovo to pay for its electricity bills can be seen as a double benefit as they are by not paying bills saving money and also failing to recognize the authority of the Kosovo run KEK company and waiting for EPS to act, while having frequent electricity cuts and shortages respectively. "Kosovo will allow EPS to establish a supply company in Kosovo, in line with its non-discriminatory obligations under the Energy Community and in accordance with the Kosovo legal and regulatory framework." ${ }^{38}$ This interesting

\footnotetext{
$36 \quad$ Ibidem

37 Kosovo, Republic of., Brief Summary of The Brussels Agreement Package, 27 August 2015, [https:// kryeministri-ks.net/wp-content/uploads/docs/Brief_summary_of_the_Brussels_Agreement_Package_270815.pdf] Accessed 20 March 2021

38 Conclusions of the EU facilitator on the implementation of the 2013 Energy Agreement, [http:// www.kim.gov.rs/eng/p20.php\#][https://kryeministri-ks.net/wp-content/uploads/docs/150825-Conclusions-on-the-Implementation-of-Energy-Agreement_en.pdf] Accessed 21 March 2021
} 
battle for a territory and the recognition of one authority or the other shows how post-conflict societies are suffering and can be ready to sacrifice their personal for a common good. This situation has lasted for more than 10 years and it has not even now yet fully been solved, although the new Serbian run Kosovo Corporation is on its way. The name of this company will be 'ElektroSever' ${ }^{39}$ and its main aim will be to collect electricity bills which would make it a more administrative than really a for profit company. "ElektroSever will be entitled to carry out billing and collection, since these are the normal activities of a supply company." 40 The aim of this company will be more of a social character and will be responsible exclusively for the four Serbian municipalities on North Kosovo. This solution is not going in line with ideas of competition but certainly the social need and it is also possible that it will once become, just as the MTS doo, part of the wider framework of Serbian companies under the framework of the A/C of Serbian municipalities. "This new company will supply electricity and may provide distribution services (such as billing, collection, maintenance and physical connection of new customers) to customers in the four northern Serb majority municipalities, and will be able to buy and sell power on the open market." ${ }^{11}$ Buying electricity on the open market will make it a player on the energy market as it will be able to use also some possible benefits from other companies formed in the framework of the BA and in particular the other Serbian run electricity trading company with a license that covers import, export and the transit of electricity. "The regulatory authorities of both sides shall, upon application, without delay, and in line with the requirements of the existing licensing framework in their jurisdiction, issue licences covering trade (import, export, transit) and supply to KEK, KEDS and EPS, respectively." ${ }^{42}$ This solution really introduces competition on the Kosovo market and boosts trade as well on fair and economic grounds. Such solutions could be seen as very good hybrid conflict resolution mechanisms as they from one side solve conflicts and from the other include competition on various post-conflict markets.

\subsection{Kosovo and its various shared resources with Serbia}

Definitely all the solutions from agreements have various benefits for either Kosovo citizens, competition enforcement or business development. "It has been reiterated that this is just the beginning of the process and that all efforts are to be

\footnotetext{
$39 \quad$ Ibidem

40 Ibidem

41 Office for Kosovo and Metohija., Arrangements regarding energy, [http://www.kim.gov.rs/eng/p04.php] Accessed 21 March 2021

42 Ibidem
} 
continued until all challenges related to business environment are removed." ${ }^{43}$ The idea behind the EU agenda is that the local stakeholders have to reach to the point where they can agree about almost everything. This is in line with EU standards and the future prerequisites for a potential EU membership, including both Serbia and Kosovo together. Both agreements are in line with the Western development ideas and although they might have slightly different focuses both are negating the influence and presence of Russian and Chinese influence. "The structure of the program focuses considerable attention on matters related to rebuilding a unified state transportation system as a major stabilizing factor for the economy." 44 All the transportation systems are foreseen to be improved and are also necessary by the respective economies and development potential, although considering the present trade war regime between Kosovo and Serbia it is more of a plan than a real possibility at the moment. Kosovo has its USA made infrastructure connecting it through Albania to the sea which network Serbia is meant to use as well according to the WA. Also while Serbia has both road and rail infrastructure supported by China and serving both Chinese and Serbian interests, potentially also useful to other countries in the wider region. On a more local perspective it is necessary for the states to learn how to use together and share the potentials and resources which could be of a mutual use, sharing Gazivoda/Ujmani Lake, as a reliable water and energy supply $y^{45}$ is just one of the unique solutions. The issue of this lake in North Kosovo has been widely debated and since it is a necessity for the Kosovo economy as a whole it will be accordingly shared in the future. "The renewable energy transformation in Germany is based partially on the strategy of decentralization and local energy supply." 46 So guaranteeing a local independence in the energy sector we can see the automatic rise in the standard of citizens and competition on the local, regional and global markets. Also by strengthening local industries development becomes more possible and instead of feeding just central companies like it is the case in both Serbia, EPS and Kosovo KEK the profit produced by SMEs can boost the economy and rise the employability. At

43 Eurochambers., Serbia and Kosovo Chambers reach agreements to boost business relations, 2013, [https://www.eurochambres.eu/wp-content/uploads/2020/02/51-SerbiaKosovoAgreements_ 13Dec13-2013-00851-01.pdf] Accessed 20 March 2021

44 Khoperskaya, L. L., The Dynamics of the Ethnopolitical Situation and Conflicts in the North Caucasus, in: Proceedings of a Russian-American Workshop, Conflict and Reconstruction in Multiethnic Societies, The National Academies Press, Washington, 2003, pp. 120 - 129

45 Republic of Kosovo., Implementation Plan of the Washington Agreements Economic Normalisation Between Kosovo and Serbia, [https://kryeministri-ks.net/wp-content/uploads/2020/10/Implementation-Plan-for-the-Washington-Agreement_19102020.pdf] Accessed 20 March 2021

46 Hartard, S., Peace and Security by Resources Self-Subsistence Strategies, in: Hartard S.; Liebert W. (eds.), Competition and Conflicts on Resource Use, London, 2015, pp. 187 - 199 
the moment Budgeting ${ }^{47}$ is an issue in Kosovo since it is an independent country with very few and limited income, therefore agreements and a good relationship with its neighbours and especially Serbia is vital for the development of SMEs as well. Development as a prerequisite for EU integration is also a regional task as the countries in Western Balkans will be forming a future union which will be unifying authorities for this region, just as the BA and WA have been setting up the basis for it. "Due to political and diplomatic circumstances, Kosovo was not included in the mini Schengen agreement." ${ }^{48}$ Now according to the WA it has to be part of this agreement and together with the CEFTA agreement there will be very little left for the respective governments to decide as markets will on a micro regional level of Western Balkans be as free, liberal and competitive as anywhere else in the EU. For various conflicts and disagreements stemming from BA and especially WA the most ideal solution is Arbitration ${ }^{49}$ which is already a standard accepted in the liberal world.

\section{COMPETITION AS A KEY TO DEVELOPMENT IN POST- CONFLICT SOCIETIES}

Competition has been declared as the most beneficial treatment of customers and citizens in regard the satisfaction of their market needs. Anyway there is a wide array of various breaches to competition rules in the framework of global economy, where states who claim competition as their main achievement do not lack the scandals regarding various missuses on the free market. "At the opposite extreme, there is the intense positive interaction between politically weighty businesses in need of state support on the world economic scene, and the bureaucracies or politicians that they seek to manipulate for their own purposes." ${ }^{50}$ Apart from

47 Kosovo, Republic of., The Republic of Kosovo Government Program on the Brussels Dialogue 2014-2018, Prishtina, 15 January 2015, [https://kryeministri-ks.net/wp-content/uploads/docs/Kosovo_Government_Program_for_Brussels_Dialogue_2014-2018_150115.pdf] Accessed 20 March 2021

In the process, deficiencies and constraints have been noted in this model of budgeting,

48 Republic of Kosovo., Implementation Plan of the Washington Agreements Economic Normalisation Between Kosovo and Serbia, [https://kryeministri-ks.net/wp-content/uploads/2020/10/Implementation-Plan-for-the-Washington-Agreement_19102020.pdf] Accessed 20 March 2021

49 Kosovo, Republic of., The Republic of Kosovo Government Program on the Brussels Dialogue 2014-2018, Prishtina, 15 January 2015, [https://kryeministri-ks.net/wp-content/uploads/docs/Kosovo_Government_Program_for_Brussels_Dialogue_2014-2018_150115.pdf] Accessed 20 March 2021

The Rambouillet Peace Conference in 1999 ended the war in Kosovo and paved the way for the liberation of Kosovo, while Vienna's status talks paved the way for Kosovo's independence. Kosovo has emerged victorious from both peace processes, while Serbia failed with the non-signing of the agreements.

50 Luttwak, E. N., From Geopolitics to Geo-Economics: Logic of Conflict, Grammar of Commerce, The National Interest, No. 20, 1990, pp. 17 - 23 
the very actual problem being faced by SMEs in losing their right to work many jurisdictions as we see today are offering state aid and are influencing an ever huge system of state incentives. As an outcome of such acts we will one day have a huge unbalance on a global level which will be outside of the scope of any competition rules previously applied. "The question of whose rules to comply with is made all the more difficult by the fact that many rules have been given extraterritorial effects which means that they can capture trades which have a weak connection, if any, to the rule-issuing jurisdiction. In such a system jurisdictional conflicts are omnipresent." ${ }^{11}$ Accordingly we are once again coming back to the actual situation post-conflict societies are facing and the unclear rules being applied to. "Special attention is being focused on creating a system of justices of the peace, who will be called upon to relieve the regular courts of less significant cases, and on monitoring the effectiveness of the operations of the regular courts and arbitration courts..." 52 The local court systems anyway do not have a big influence on the global markets and as is the case in USA and Huawei conflict the enforcement mechanisms of USA are not able to reach out to China but are able to limit its presence on various other markets just as is the case with the recent Washington Agreement for territories of Serbia and Kosovo.

\subsection{Competition and the rule of law in the EU framework}

The overall framework and implications of EU regarding the resolution of the conflict between Serbia and Kosovo are using a holistic approach. The Brussels Agreement is not solving just one issue but systematically advancing and transforming the whole conflict taking various perspectives. "Only a wise use of all resources together and doing this by incorporating socio-cultural (moral), ecological and economic considerations, seems to be the most advantageous and promote successful emerging technology." ${ }^{33}$ If the solutions of the BA show the necessary and expected results we can expect to see the divided sides move closer to the resolution of disagreements regarding even more capital solutions, in particular the Trepcha mines, various state properties and of course the future status questions in both regional and EU connotations. "It is true that a strong link between unitary and more or less homogeneous states, on the one hand, and economic and

51 Marjosola, H., Regulate Thy Neighbour: Competition and Conflict in the Cross-border Regulatory Space for OTC Derivatives, EUI Working Paper, Law 2016/01, 2016, pp. 1 - 23

52 Khoperskaya, L. L., The Dynamics of the Ethnopolitical Situation and Conflicts in the North Caucasus, in: Proceedings of a Russian-American Workshop, Conflict and Reconstruction in Multiethnic Societies, The National Academies Press, Washington, 2003, pp. 120 - 129

53 Zepf, V. et al., Strategic Resources for Emerging Technologies, in: Hartard S.; Liebert W. (eds.), Competition and Conflicts on Resource Use, London, 2015, pp. 259 - 272 
social advancement, on the other, is not imperative, but it is far from clear that nation states are weakening, declining, eroding, and withering away because of transnational economic forces." ${ }^{44}$ Apart from the EU it is the most actual example of cooperation after a conflict on the European continent, therefore it is not acceptable to expect Kosovo not to cooperate with Serbia even if Serbia declines its recognition. It is further expected to see the UNMIK and EULEX missions in the future at Kosovo as well without a clear intention of when and if Kosovo will gain its full UN membership and sovereignty after all. "The authorities implementing the legislations should also have clear and compatible mandates." 55 In line with this the recent trade war between Kosovo and Serbia is disrespecting not just CEFTA standards but is against the wider EU expectations too.

\subsection{Competition and the rule of law in Kosovo}

In the past 20 years of post-conflict development Kosovo has made steps towards the market economy and competition in particular. One of the biggest obstacles to the development of the economy is corruption and the control of the economic activities by political elites. "Abuse of a dominant position by one or more enterprises on the corresponding market is prohibited..." Although well regulated the very harsh business environment in Kosovo has resulted in a fact that multinational companies are not investing much here. The recent formation of Serbian companies might not enhance competition much but certainly the administrative obstacles their formation has faced are not encouraging, and the whole process is still not over yet. "Should it not be possible to reach a common settlement within 6 months, both parties agree to submit these claims to international arbitration." 57 The agreements themselves might not need to be arbitrated but some certain procedures and obstacles could be clarified more through arbitration. It is very important to outline that such agreements like BA and WA in the framework of conflict resolution should not be challenged in their basic form, also if parties can't agree about the actual meaning of the agreement it has very little to do with arbitration on the end. Therefore it is necessary for not just the government but to the people of Kosovo to understand that such agreements have been done in their

54 Khazanov, A. M., Ethnic and National Conflicts in the Age of Globalization, in: Proceedings of a Russian-American Workshop, Conflict and Reconstruction in Multiethnic Societies, The National Academies Press, Washington, 2003, pp. 162 - 167

55 Marjosola, H., Regulate Thy Neighbour: Competition and Conflict in the Cross-border Regulatory Space for OTC Derivatives, EUI Working Paper, Law 2016/01, 2016, pp. 1 - 23

56 Art. 11 of the Law on Protection of Competition, Official Gazette of the Republic of Kosovo, Law No. 03/L-229, 07 October 2010

57 Office for Kosovo and Metohija., Arrangements regarding energy, [http://www.kim.gov.rs/eng/p04.php] Accessed 21 March 2021 
best interest, and they should fully live up to use the opportunities arising from them. "Surely, liberal democracy per se is not a solution for ethnic and national problems." ${ }^{8}$ Ethnic and national problems could be overcome and there could be very nice examples for such, as one is the very close cooperation of Albanian government with Serbia on the formation of the Mini Schengen, where Kosovo will also belong one day according to the WA as least. The Mini Schengen agreement is meant to have the 6 Western Balkan non EU member countries as members and by introducing the free movement of persons have one day possibly the freedoms such as the ones present in the EU, including competition after all.

\section{CONCLUSION}

Although competition is an excellent tool for development and in particular regarding societies with a post-conflict background it is hard to always guarantee and achieve it. In the framework of a post-conflict development there are multiple sources which could influence economic activities. As we have seen it on the case of Serbia and Kosovo, these two countries are surrounded with various influences which are trying to help them but also secure own interests. The crossroads of the Balkans are tremendously influencing countries like Serbia and Kosovo equally and mutually but they are also influenced by USA and EU. On the other side Serbia also have a considerable influence stemming from Russia and China. This global competition of power is ultimately related to the fact of sharing the markets for both the supply of resources and goods placement on markets. All the powers are aiming at gaining a higher level of support of local political elites and citizen altogether. With both The Brussels Agreement and The Washington Agreement there have been a wide array of changes agreed which are waiting for their full implementation. Regarding competition it is very important to outline the future establishment of various enterprises regarding telecommunications, energy, water and economic development in post-conflict Kosovo. Even with the hesitation of the Kosovo government to fully apply The Brussels Agreement it was recently strengthened by The Washington agreement where disagreements have been solved and a broader economic cooperation has been agreed. Regarding competition we can see that some areas have been de-monopolized and also regulated for the first time which gave a complex situation where conflicts are solved in a nationally acceptable way. Competition locally has been achieved to a certain level and on a wider global level we can predict that it will continue offering similar outcomes in other post-conflict societies. Limiting the local economies and binding them to

58 Khazanov, A. M., Ethnic and National Conflicts in the Age of Globalization, in: Proceedings of a Russian-American Workshop, Conflict and Reconstruction in Multiethnic Societies, The National Academies Press, Washington, 2003, pp. 162 - 167 
certain powers is not just additionally polarizing the world but also undermining the efforts to achieve democracy, development and full competition ultimately.

\section{REFERENCES}

\section{BOOKS AND ARTICLES}

1. Bayramov, A., Conflict, cooperation or competition in the Caspian Sea region: A critical review of the New Great Game paradigm, Caucasus Survey, 11 Jun 2020, pp. 1 - 20

2. Bringa, T., Transition and Conflict in Multiethnic Postsocialist Societies: The Case of Bosnia-Herzegovina in: Proceedings of a Russian-American Workshop, Conflict and Reconstruction in Multiethnic Societies, The National Academies Press, Washington, 2003, pp. $168-181$

3. Casier, T., From logic of competition to conflict: understanding the dynamics of EU-Russia relations, Contemporary Politics, Vol. 22, No. 3, 2016, pp. 376 - 394

4. Hageluken, C., Closing the Loop for Rare Metals Used in Consumer Products: Opportunities and Challenges, in: Hartard S.; Liebert W. (eds.), Competition and Conflicts on Resource Use, London, 2015, pp. 103 - 119.

5. Hartard, S., Peace and Security by Resources Self-Subsistence Strategies, in: Hartard S.; Liebert W. (eds.), Competition and Conflicts on Resource Use, London, 2015, pp. 187 - 199

6. Khazanov, A. M., Ethnic and National Conflicts in the Age of Globalization, in: Proceedings of a Russian American Workshop, Conflict and Reconstruction in Multi-ethnic Societies, The National Academies Press, Washington, 2003, pp. 162 - 167

7. Khoperskaya, L. L., The Dynamics of the Ethnopolitical Situation and Conflicts in the North Caucasus, in: Proceedings of a Russian American Workshop, Conflict and Reconstruction in Multiethnic Societies, The National Academies Press, Washington, 2003, pp. $120-129$

8. Luttwak, E. N., From Geopolitics to Geo-Economics: Logic of Conflict, Grammar of Commerce, The National Interest, No. 20, 1990, pp. 17 - 23

9. Marjosola, H., Regulate Thy Neighbour: Competition and Conflict in the Cross-border Regulatory Space for OTC Derivatives, EUI Working Paper, Law 2016/01, 2016, pp. 1 - 23

10. Shaikh, A., Capitalism: competition, conflict, crises, Oxford University Press, Oxford, 2016

11. Wittek, R., Resource competition and violent conflict: Cross-cultural evidence for a socioecological approach, Zeitschrift fur Ethnologie, No. 115, 1990, pp. 23 - 44

12. Zepf, V. et al., Strategic Resources for Emerging Technologies, in: Hartard S.; Liebert W. (eds.), Competition and Conflicts on Resource Use, London, 2015, pp. 259 - 272

\section{LIST OF NATIONAL REGULATIONS, ACTS AND COURT DECISIONS}

1. Republic of Kosovo,. Law No. 04/L-199 on ratification of the First International Agreement of Principles Governing the Normalization of Relations between the Republic of Kosovo and the Republic of Serbia, [https://gzk.rks-gov.net/ActDocumentDetail.aspx?ActID=11205] Accessed 21 March 2021 
2. Law on Protection of Competition Art. 11, Official Gazette of the Republic of Kosovo, Law No. 03/L-229, 07 October 2010

3. Law on Protection of Competition Art.15, Official Gazette of the RS No. 51/2009 and $95 / 2013$

\section{WEBSITE REFERENCES}

1. Business Registration Agency of Kosovo., Društvo Elektrosever D.O.O., [https://arbk.rksgov.net/page.aspx?id=2,38,174962] Accessed 20 March 2021

2. Conclusions of the EU facilitator on the implementation of the 2013 Energy Agreement, [http://www.kim.gov.rs/eng/p20.php\#] [https://kryeministri-ks.net/wp-content/uploads/ docs/150825-Conclusions-on-the-Implementation-of-Energy-Agreement_en.pdf] Accessed 21 March 2021

3. EPS JP PK „KOSOVO“ - Obilić, O nama, [http://pkkosovo.rs/]Accessed 20 March 2021

4. EUROCHAMBERS., Serbia and Kosovo Chambers reach agreements to boost business relations, 2013, [https:/www.eurochambres.eu/wp-content/uploads/2020/02/51-SerbiaKo sovoAgreements_13Dec13-2013-00851-01.pdf] Accessed 20 March 2021

5. Kosovo, Republic of., Brief Summary of The Brussels Agreement Package, 27 August 2015, [https://kryeministri-ks.net/wp-content/uploads/docs/Brief_summary_of_the_Brussels_ Agreement_Package_270815.pdf] Accessed 20 March 2021

6. Kosovo, Republic of., The Republic of Kosovo Government Program on the Brussels Dialogue 2014 - 2018, Prishtina, 15 January 2015, [https://kryeministri-ks.net/wp-content/uploads/docs/Kosovo_Government_Program_for_Brussels_Dialogue_2014-2018_150115. pdf] Accessed 20 March 2021

7. MTS D.O.O., O Nama, [https://mtsdoo.com/o-nama/] Accessed 20 March 2021

8. Office for Kosovo and Metohija and Office for the Coordination of Affairs in the Process of Negotiation with the Provisional Institutions of Self-Government in Priština., Progress Report on the Dialogue Between Belgrade and Priština (Covering the period from May 1 to December 15, 2018), [http:/www.kim.gov.rs/doc/pregovaracki-proces/Sestomesecni\%20 izvestaj\%20o\%20dijalogu\%20dec\%202018\%20\%2011\%2002\%202019\%20en.pdf] Accessed 20 March 2021

9. Office for Kosovo and Metohija., Annex 3 of the Memorandum on understanding between Chamber of commerce and industry of Serbia and Kosovo Chamber of Commerce, [http://www.kim.gov.rs/doc/pregovaracki-proces/2.2\%20Annex\%203\%20MoU\%20PKSPKK\%20febr\%202015\%20eng.pdf] Accessed 20 March 2021

10. Office for Kosovo and Metohija., Arrangements regarding energy, [http://www.kim.gov.rs/ eng/p04.php] Accessed 21 March 2021

11. Office for Kosovo and Metohija., Conclusions of the EU Facilitator on Telecoms, 13 November 2016, [http://www.kim.gov.rs/eng/p23.php] Accessed 22 March 2021

12. Office for Kosovo and Metohija., Telecommunications, [http://www.kim.gov.rs/eng/p05. php] Accessed 22 March 2021

13. Republic of Kosovo., Implementation Plan of the Washington Agreements Economic Normalisation Between Kosovo and Serbia, [https://kryeministri-ks.net/wp-content/up- 
loads/2020/10/Implementation-Plan-for-the-Washington-Agreement_19102020.pdf] Accessed 20 March 2021

14. Republic of Serbia, Brussels Agreement, [https://www.srbija.gov.rs/cinjenice/en/120394] Accessed 21 March 2021 